\title{
Barriers And Challenges Restraining Zimbabwean Banks In Going Multinational
}

\author{
Courage Mlambo, University of Fort Hare, South Africa \\ David Mapondera, National University of Science and Technology, South Africa \\ Morris Tenderere, University of Fort Hare, South Africa
}

\begin{abstract}
This paper investigates the barriers and challenges restraining Zimbabwean banking institutions in going multinational. The paper drew attention from the fact that although multinational banking had increased drastically in the last two decades, Zimbabwean banks have failed to go multinational.

Findings from this study indicate that cultural distance, government policy, information asymmetry, level of technology, legal and regulatory barriers and barriers to entry are the main challenges that restrain Zimbabwean banks from going multinational. The paper also examines policy options to address the challenges faced by Zimbabwean banks when going multinational.
\end{abstract}

Keywords: Multinational Banking; Foreign Banking; Economic Globalisation; Indigenous Banks; Economic Globalisation

\section{INTRODUCTION}

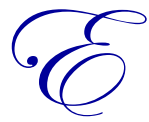

conomic globalisation has dominated the global economy over the last two decades which has seen the world becoming more integrated, not just through the movement of people but through financial flows.

An important aspect of the economic globalisation process has been the development of cross-border banking movements. Lensink and Hermes (2003) note that multinational banking activity has grown quickly due to the globalisation of capital markets, increased FDI activities, and the liberalisation of financial markets. Economic globalisation has been characterized by an exceptional degree of global monetary and financial movements. Crossborder banking movements have increased drastically and banks from developed and the developing world have established presence in other countries (Claessens and Van Horen, 2012).

Economic globalisation has made the banking industry go into a state of transformation and the increase in global economic integration has significantly changed the size of cross-border banking movements. Marin (2010) held that since the 90's, many countries undertook global financial intergration by reducing the barriers to crossborder financial transactions and an increased participation of multinational banks. This, inter alia, has led to an increase in cross-border banking movements. Cull and Perria (2010) states that "local profit opportunities, the absence of barriers to entry, and the presence of mechanisms to mitigate information problems have been the main factors driving foreign bank entry across both the developed and developing countries". Multinational banking provides, to the host country, an important means of capital and a means for creating a stable and long-lasting financial source. It also serves well development, as well as growth and employment prospects. In addition, it also promotes transfer of technology and it contributes to productivity and income growth.

Going multinational also provides banks with several benefits. Grubel (1985) notes that multinational banking makes it possible to generate large economies of operation for the individual banks and it also provides room for diversification of business and risk. Multinational banking presents banks with benefits in the form of opportunities in gaining market share and improved service provision through the use of state-of-the-art technology. These benefits will, in turn, raise the profit of the bank. However, many banks in African countries, such as Zimbabwe, have not been exploiting these opportunities. So the question arises, "what are the barriers that 
Zimbabwean banks face when going multinational?" A number of studies have shown that banks from developing countries encounter many challenges when they go multinational. Mathews (2002), cited in Petrou (2007), revealed that banks from developing countries are smaller, less international and may not possess ownership advantages when they go multinational. Zimbabwean banks are no exception; they face huge challenges in going multinational. Lack of expansion, by Zimbabwean banks into foreign markets, remains a problem. The question of why banks in Zimbabwe are failing to go abroad is an empirical issue and, as a result, it needs to be investigated. This study, therefore, seeks to investigate the barriers and challenges constraining Zimbabwean banking institutions in going multinational.

\section{A REVIEW OF THE ZIMBABWEAN BANKING SECTOR}

The Zimbabwe's Banking sector is relatively substantial and sophisticated. Most of the banks in the Zimbabwean banking sector are commercial banks, but there are also merchant banks, building societies and a savings bank. The Reserve Bank oversees, monitors and regulates the banking system in Zimbabwe. The Zimbabwean banking sector has emerged from severe financial damage resulting from the protracted political and economic turmoil that Zimbabwe went through between 2002 and 2009. The economy in Zimbabwe shrunk significantly after 2002 and by 2009 , Zimbabwe had been blighted by probably its worst political and economic crisis which significantly affected every sector of the economy, including the bank sector which was near complete collapse. Banking transactions in the local currency (Zimbabwean dollar) were depressed due to the value of the Zimbabwean dollar which had lost its relevance as a store of value and medium of exchange. Financial and monetary transaction in local currency, through the banking and financial system, declined significantly and the Zimbabwean financial sector faced a crisis that nearly ruined the banking system.

In 2009, the government introduced a multi-currency system which brought stability in the financial sector. Initially, the multi-currency system did not produce significant results in the banking business. Trust in the financial sector had eroded due to the political and economic crisis. However, as the economy of Zimbabwe recovered from its protracted crisis, the public restored their confidence in the banking industry and started to keep their money inside the formal banking system which led to an expansion in the deposit base. Despite these positive changes, the Zimbabwean banking sector still faces a number of problems. The Reserve Bank of Zimbabwe (2013) concurs and states that "liquidity shortages, together with the absence of an active inter-bank market, limited access to affordable external credit lines, and absence of Lender of Last Resort still compounds the domestic operating environment for banks". In addition, adverse economic developments, together with banking mismanagement at several banks, provide a ground for liquidity problems. In January 2013, there were 22 banking institutions in Zimbabwe. The composition of the Zimbabwean banking sector is shown in Table 1.

Table 1: Structure Of The Zimbabwean Banking Sector

\begin{tabular}{lc}
\hline \multicolumn{1}{c}{ Type of Institution } & Number \\
\hline Commercial Banks & 16 \\
Building Societies & 3 \\
Merchant Banks & 2 \\
Savings Banks & 1 \\
Total Banking Institutions & 22 \\
\hline
\end{tabular}

Source: Reserve Bank of Zimbabwe (2013)

Table 1 shows that there are only three building societies, two merchant banks and only one savings bank, which is the Post Office Savings bank. The bulk of Zimbabwe's banks are commercial - $72 \%$ fall under this category. Commercial banks offer current and deposit account facilities and provide loans and overdrafts to needy business organizations and individuals. They also offer foreign exchange facilities, including accepting foreign exchange deposits. Table 2 shows some of the commercial banks in Zimbabwe. 
Table 2: List Of Some Of The Registered Commercial Banking Institutions In Zimbabwe

\begin{tabular}{|c|c|c|c|}
\hline Bank Name & $\begin{array}{c}\text { Date of } \\
\text { Establishment }\end{array}$ & $\begin{array}{l}\text { Number Of } \\
\text { Employees }\end{array}$ & $\begin{array}{c}\text { Number Of } \\
\text { Branches }\end{array}$ \\
\hline Barclays Bank of Zimbabwe Limited & 1896 & 1115 & 34 \\
\hline Agricultural Development Bank of Zimbabwe & 1999 & 913 & 24 \\
\hline Allied Bank & 2005 & 302 & 19 \\
\hline African Banking Corporation & 1965 & 151 & 2 \\
\hline CBZ limited & 1991 & 748 & 24 \\
\hline Ecobank & 2002 & 106 & 6 \\
\hline FBC Bank Limited & 1997 & 460 & 14 \\
\hline Interfin Bank & 1999 & N/A & 12 \\
\hline Intermarket Banking Corporation & 2002 & 64 & 1 \\
\hline Kingdom Bank Limited & 1997 & 495 & 25 \\
\hline MBCA Bank Limited & 1956 & 260 & 5 \\
\hline NMB Bank Limited & 1992 & 279 & 9 \\
\hline Stanbic Bank Zimbabwe Limited & 1965 & 631 & 18 \\
\hline Standard Chartered Bank Zimbabwe Limited & 1892 & 852 & 24 \\
\hline Trust Bank & 1995 & 177 & 9 \\
\hline ZB Bank Limited & 1989 & 963 & 38 \\
\hline
\end{tabular}

Source: Reserve Bank of Zimbabwe (2013)

The majority of banks in Zimbabwe fall into the private sector, which is wholly owned by companies and individuals. The Zimbabwean banking sector has been dominated by local banks - twenty of them indigenous. There are only five foreign banks which are Standard and Chartered, Stanbic, Barclays, Merchant bank of Central Africa (MBCA), and the Central African Building Society (CABS). The bulk of local banking institutions have not gone international.

\section{LITERATURE REVIEW}

Studies have identified several factors that influence cross-border banking movements. Blandon (1998) notes that Ball and Tschoegl (1982) are some of the pioneers in investigating factors that influence banks in going multinational. Findings from their study showed that multinational banking was determined by bank size, its experience in multinational business operations, and the distance between the host country and the bank's country of origin. Similar results were found by Ursacki and Vertinsky (1992) who investigated multinational banking in Korea and Japan. Results from their study supported Ball and Tschoegl's (1982) findings. Results from their study showed that bank size and multinational banking experience were important determinants of multinational banking. Multinational banking experience constitutes an advantage in encouraging multinational banking. Literature by Blandon (1998) suggests that when firms acquire more international experience, the uncertainty levels regarding operating in foreign markets will reduce. In another study, Di Antonio, Mariotti and Piscitello (2003), cited in Herrero and Simón (2003), saw international multinational banking experience as significantly important for banks to invest in foreign banking markets.

Another line of literature supports the "follow the customer" approach. This line of literature stresses that banks go abroad to follow their customers. Nigh et al. (1986) showed that United States banks that went multinational did so in an attempt to cater to the needs of United States firms that operated abroad. A similar result was found by Hultman and McGee (1989) who showed that foreign banks operating in the United States penetrated the United States banking market to offer financial services to their home country customers. Berger et al. (1995), cited in Hryckiewicz and Kowalewski (2008), argue that larger banks have diversified customers globally and therefore they have an incentive to follow these customers when they move abroad. Lee (2003) found that foreign banks, before the financial crisis in Asia, primarily supported clients from their home countries.

Ownership-specific advantages have also been seen to play a huge role in cross-border banking. Guler and Guillén (2009) ascertain that firms with "technological capabilities, marketing know-how, branding skills, and/or organizational capabilities" are likely to be successful when entering foreign markets. Literature has also emphasised that banks coming from more modern and sophisticated banking systems compete better in foreign markets (Blandon, 1998). Miller and Parkhe (1998), however, found that banks are likely to invest in countries 
where the banking system is well developed, as a means to develop and improve their services. Cultural differences can act as either an incitement or a deterrent for cross-border banking movements. Kessapidou and Varsakelis (2002) showed that national cultural differences influenced both the entry mode and the perceived difficulty surrounding the intergration of foreign personnel in the operation. Banerjee and Tiwari (2009) bring in additional support to these findings establishing that on Emergence of Indian Multinationals in Germany, major challenges that firms faced included cultural differences between India and Germany.

Foreign regulatory framework can also have a large bearing on multinational banking decisions. Naaborg (2007) finds that institutional factors are a determinant of multinational banking. These institutional factors, according to Naaborg (2007), include financial regulation issues, the quality of the law enforcement, information costs, and the host country's openness toward foreign bank entry. Focarelli and Pozzolo (2000) found judicial efficiency as a determinant of foreign bank entry. Globerman and Shapiro (2002) found that better governance leads to more foreign direct investment inflows. Galindo et al. (2003) found that countries with less corruption attract foreign bank participation. Dixit (2012) notes that corruption, together with legal features such as the rule of law and the regulatory environment, receive much publicity and, as a result, they have an effect on the attitude of banks in making decisions regarding investing abroad.

\section{METHODOLOGY}

This section provides an outline of the research methodology used in this study and discusses the scope of the study, population and sampling, data collection and analysis procedure.

\section{Scope Of The Study}

The study was carried out in the city of Harare, encompassing Zimbabwean banking institutions only. Harare has been chosen because it carries the hub of the head offices of banking institutions. The time period covered by the study was between 2005 and 2012 .

\section{Research Population And Sampling Method}

According to the Reserve Bank of Zimbabwe (2013), there are 22 banking institutions in Zimbabwe and they employ over 8,000 people. However, most of the staff in the banking sector have no knowledge of multinational banking and, as a result, they could not participate in this study. Bank directors and marketing managers were then considered to participate in the study. A judgemental sampling technique was used to select respondents who had multinational banking knowledge. This technique made it possible to use judgment to select respondents that best answer the research questions and meeting of objectives (Creswell, cited in Chikoko, 2014). Bank managers and bank marketing managers were considered to be the respondents of the study.

\section{Data Collection Instruments}

The study used both primary and secondary data. Primary data sources are those that provide information concerning the issue at hand and are collected by going into the particular field of study. Secondary data research involves gathering of information that already exists, which, in this case, included journals, newspapers and the internet.

\section{Primary Data}

The study used questionnaires and interviews. The research was carried out through the use of structured questionnaires. The targeted population was easy to control through the use of questionnaires, as they gave guidelines to the respondents. Self-completion of questions helped to generate more reliable and valid information. They were also economic in terms of time management, as they were drop and pick instruments. The study also used a structured interview to gather information. Interviews were used to gather information that the questionnaire could not capture adequately, and interviews also clarified some issues on the perceptions of multinational banking by local banking institutions. 


\section{Secondary Data}

A significant amount of information was gathered from secondary sources of research. Information was sourced from journals, RBZ, government publications, banking bulletins and internet sources. Information that was obtained from secondary sources was used to construct the questionnaires and interviews.

\section{Data Coding And Analysis}

The data were transcribed, translated, coded and entered in SPSS (Version 18). Descriptive statistical functions were used to calculate percentages of response in favour of particular characteristics both in the questionnaire and interviews.

\section{DATA PRESENTATION AND ANALYSIS}

The primary objective of the research was to analyse the barriers and challenges that Zimbabwean multinational banks face in going multinational. The findings indicate that several factors act as barriers to multinational banks in them going multinational. This section will present the study's findings.

\section{Analysis Of Response Rate}

The research got a 77 percent response rate from both questionnaires and interviews from a sample of marketing personnel and branch managers. The other 23 percent of the respondents were either very busy during the course of the research and could not - although willing - be available to provide information or were unwilling to release information with reasons that it was confidential. Table 3 shows the response rate.

Table 3: Response Rate

\begin{tabular}{lccc}
\hline Respondent Category & Sample & Respondents & Response Rate \\
\hline Bank Managers & 15 & 12 & $80 \%$ \\
Marketing Personnel & 20 & 15 & $75 \%$ \\
Total & 35 & 27 & $77 \%$ \\
\hline
\end{tabular}

Source: Primary data

\section{FINDINGS}

The main focus of this study was to investigate the challenges and barriers that multinational banks in Zimbabwe face in going multinational. Findings from the study are herein to be presented in the form of pie charts, tables, and graphs as preferred.

\section{Desire To Exploit Foreign Markets}

Findings from this study ascertained that most of the banking institutions in Zimbabwe want to become multinationals. Figure 1 shows what several Zimbabwean banks would want to establish if they go multinational.

As a means of introducing themselves to foreign markets, $30.2 \%$ of those banking institutions that have never entered foreign markets revealed that they would choose representative offices. The choices were supported by the overriding advantage of being the entry strategy that allows the bank to taste the waters in multinational banking without huge capital investments. The findings concur with Blandon's (1998) assertion that "the representative office is the most economical of overseas banking organizational forms". Representative offices, correspondent banking and agencies require low-cost start up capital. Branch banking and correspondent bank were the next better preferred strategies, the reason being that correspondent bank requires relatively low-cost start up and branch banking allows the bank to fully participate in the banking activities of the host country.

These finding are, to some extent, consistent with what has been found by previous studies. For instance, Cerutti (2007) asserts that among all of the organizational forms of representation abroad, the subsidiary and the 
affiliate bank are generally the two that make it possible for MNBs to constitute quickly, such a network. However, it should also be noted that the choice of the subsidiary depends heavily on the availability of an important network of potential customers in the host country.

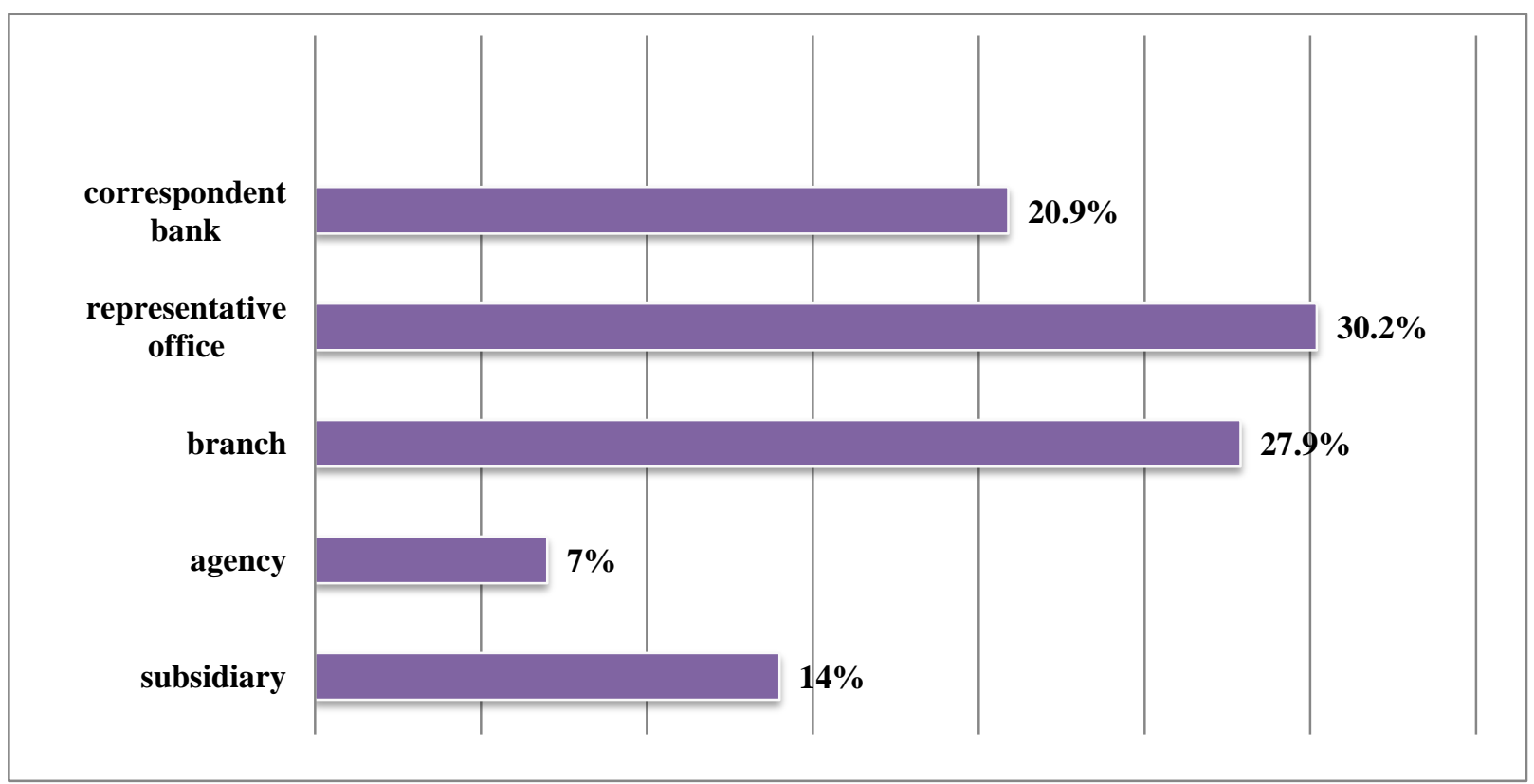

Source: Primary data

Figure 1: Banking Offices By Aspirants

\section{Challenges Faced In Multinational Banking}

This section presents factors that were cited by respondents as the main challenges that banks face in going multinational. Respondents cited three main challenges that hinder them in entering foreign markets - adjusting to the foreign environment, political risk, and banking mismanagement. Figure 2 shows the challenges that banks faced in going multinational.

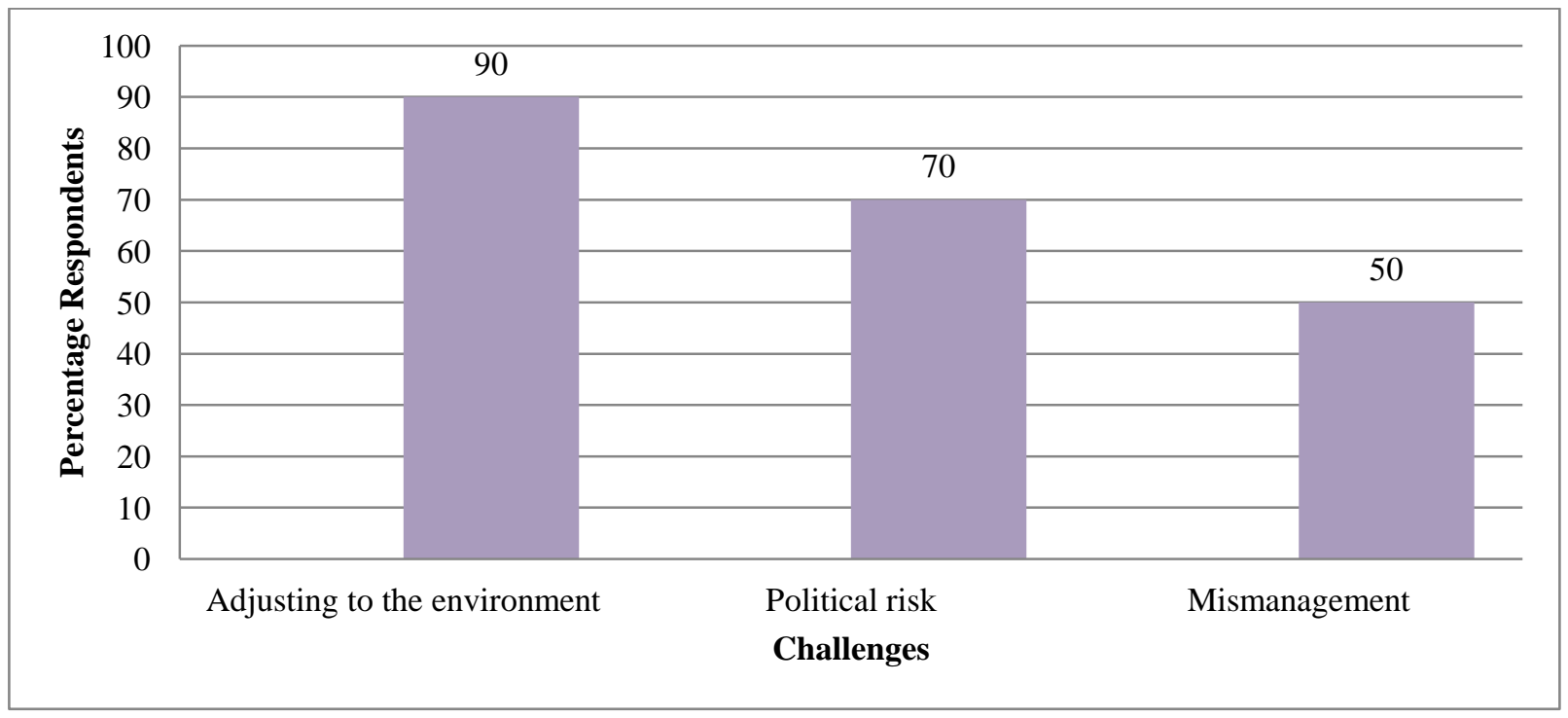

Source: Primary data

Figure 2: Challenges In Multinational Banking 
Some local banks have not made attempts to penetrate foreign markets due to challenges faced in going multinational. The question on challenges got an outstanding response and, as shown in Figure 2, the following are the challenges that were cited:

- $\quad$ Adjusting To The Foreign Environment And Lack Of International Experience - All the respondents cited this as a challenge and also mentioned the fact that it's a challenge faced by several businesses moving from their home country. The lack of experience in multinational banking may cause an inexperienced bank to be out-performed by well-established international banking institutions. Blandon (1998), Mutinelli and Piscitello (2001), and Di Antonio, Mariotti and Piscitello (2003) also saw international experience as crucially important for banks to expand abroad.

- $\quad$ Managing Political Risk -Since banks have no control over political risk, respondents cited this as a major challenge in multinational banking since it may lead to poor performance or takeover of the unit established in the foreign country. The results concur with those of Spremann et al. (2000), cited in Hamadou (2012), who stressed that political instability does not encourage MNBs to establish themselves abroad through branch forms. Azzimonte and Sartre (2007), Buthe et al. (2008), Iloiu (2008), and Aguiar et al. (2011) also stressed that the presence of a proven political risk has been an issue that multinationals worry over when considering investing abroad.

- $\quad$ Bank Mismanagement - Respondents admitted that local banks still had problems with managing their own businesses. Mismanagement in banks has been a source of concern in the Zimbabwean financial sector. The RBZ (2013) stressed that there is mismanagement in some local banks which has created problems. Mismanagement in banks resulted in several banks being placed under curatorship by the RBZ. Since 2004, more than 20 banking institutions have collapsed because of bank mismanagement. Poor corporate governance, overstatement of capital, abuse of depositors' funds, poor risk management systems, and chronic liquidity challenges are management factors that are affecting the banking sector (Njanike, 2009; Mphambela, 2012; Tsarwe, 2014).

\section{Barriers To Multinational Banking}

This section presents empirical findings in reference to the barriers to multinational banking. The five major factors were noted as barriers and are shown in Figure 3.

Figure 3 shows that entry barriers, legal and regulatory barriers, and government policies are the dominant factors as briefly explained below.

\section{Cultural Distance}

Respondents argued that they would prefer to offer their banking services to customers in countries that typically share cultural similarities with Zimbabwe. The respondents stressed that only a handful of countries had cultural similarities with Zimbabwe. One respondent argued that people in Muslim-majority countries are used to the culture of Islamic banking and they do not want any other form of banking other than Islamic. This makes it very hard to penetrate the banking markets in Muslim-majority countries. It can, thus, be said that higher cultural distance will make cross-border banking movements less likely to occur. Kessapidou and Varsakelis (2002), Buch and De Long (2004), Muza (2007), and Wu (2008) also determined that culture influences matter in multinational banking. Muza (2007) proved, in Zimbabwe, that Zimbabwean banks encountered cultural barriers when entering regional markets, which hindered their cross-border movements.

\section{Information Asymmetry}

Banks may face acute difficulties in gathering the sort of information that may be needed in multinational banking. Respondents said that information asymmetry may lead to adverse selection by the foreign banks, which may ultimately lead to poor credit decisions. Zhang, Shan and Wang (2013) found that asymmetric information, inter alia, is a significant determinant of foreign banks' location strategies. Earlier, Wu, Jeon and Luca (2010) had revealed that the unfavourable information asymmetry that foreign banks face also affects the establishment of foreign subsidiaries. In addition, Coval and Moskowitz (1999) had earlier found that information asymmetry causes biases in the investment of market participants and had negative implications on multinational business operations. 


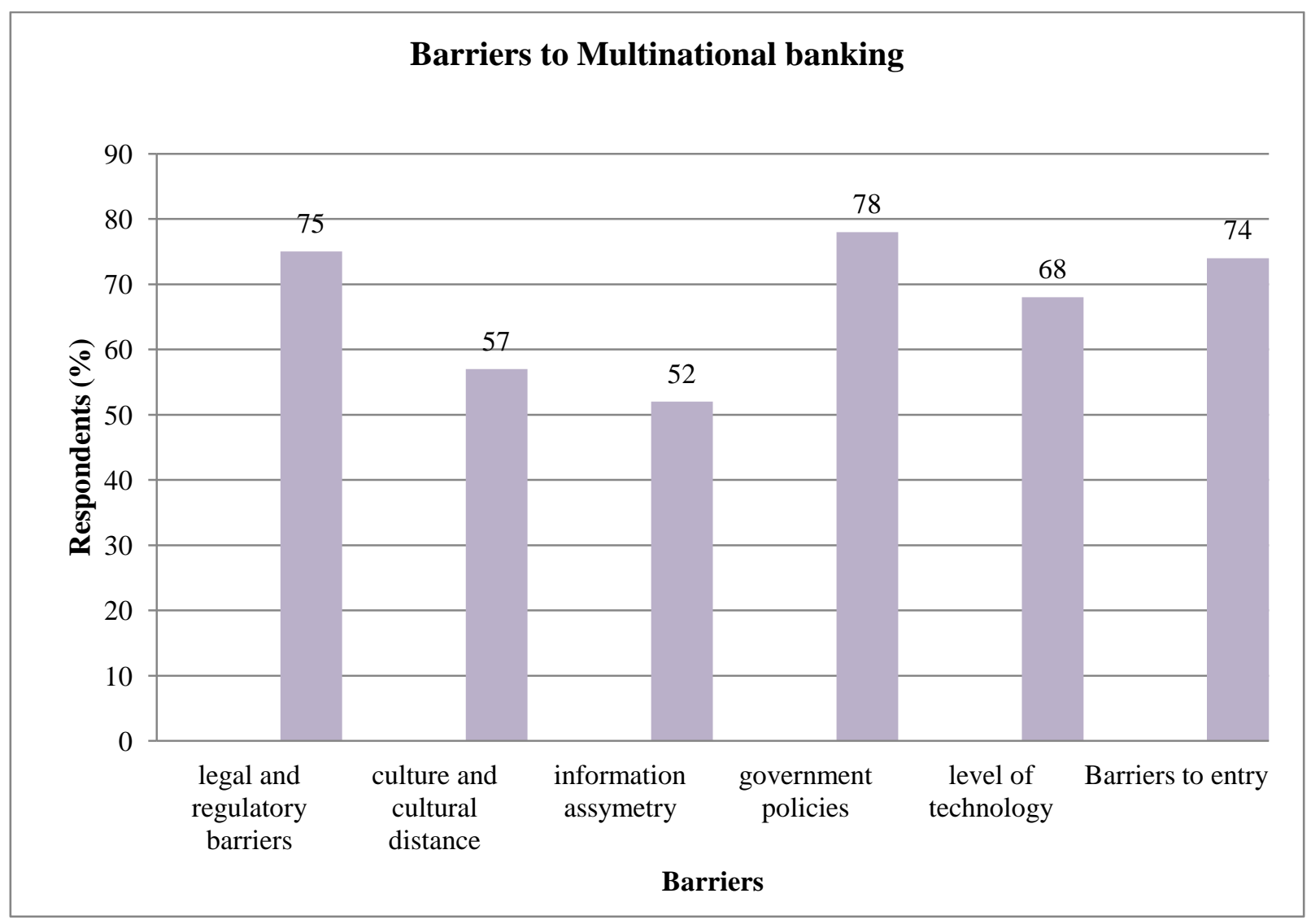

Source: Primary data

Figure 3: Barriers To Multinational Banking

\section{Government Policies}

Respondents stressed the role of government policies in influencing the decision to establish banking offices abroad. Respondents argued that local governments usually implement policies that benefit local institutions at the expense of foreign institutions. In this case, government policies may act as a deterrent to multinational banking. The findings of this study concur with those of Dixit's (2012) study which found that government policies, such as outright expropriation of foreign firms, tax regimes, rule of law, and corruption, can make foreign firms insecure in various ways. Several other studies have shown that government policies are a significant determinant of foreign banking locational strategies. Boot (1999), cited in Hryckiewicz and Kowalewski (2008), also, to a larger extent, support the findings of this present study. Boot (1999) cited in Hryckiewicz and Kowalewski (2008) that governments may want to have the largest banks in their countries to be owned by locals. This can be a hindrance to the entry of large foreign banks.

\section{Legal And Regulatory Barriers}

It was realised from the respondents' responses that regulatory barriers can act as a hindrance to multinational banking. If the regulator in the host country implements a stricter regulatory framework, this may pose challenges to new entrants, especially foreign banks. Respondents also noted that regulatory framework being used in some of the countries is more tough on foreign entities; for example, foreign banks in some countries are forced to comply with higher minimum capital requirements as compared to domestic banks with lower capital requirements to follow. Our results corroborate those of Galindo et al. (2002), Cerutti (2007), and Naaborg (2007). 
These studies also provided evidence that regulations matter in determining the pattern of multinational banking. For instance, Naaborg (2007) found that financial regulations and quality of law enforcement were among other factors that act as determinants of the choice of going abroad by banks.

\section{Level Of Technology}

Respondents cited that the level of technology may hinder foreign expansion. This is usually the case when the bank's home country is lagging behind in terms of technology as compared to that of the foreign country. The bank will be forced to adapt to the new technology in the foreign markets which presents a major challenge since it is costly to adopt and implement new technology. This is usually the case when a bank's home country is undeveloped and it intends to penetrate markets in developed countries for the first time. The findings from this study are consistent with both economic theory and empirical literature (Ursacki and Vertinsky, 1992) and Guler and Guillén, 2009). Guler and Guillén (2009) ascertain that firms with organizational capabilities, marketing know-how, technological capabilities, and branding skills tend to be successful when entering foreign markets. Literature has also emphasised that multinational banks from countries with more competitive banking systems are able to compete abroad.

\section{Barriers To Entry}

Respondents cited barriers to entry as a decisive factor that influences their decisions whether or not to go multinational. Government-created barriers, such as capital requirements and other stringent measures, were examples that acted as barriers to Zimbabwean banks in going multinational. These barriers are created by the host country to make it hard for foreign banks to penetrate their financial markets. The findings are supported by literature of Cerutti (2007) and, to a lesser extent, Miller and Parkhe (1998). Cerutti (2007) asserts that restraints imposed on multinational banks, by both the host and home countries, negatively affect the choice of the organisation form of representation. Put differently, barriers to entry can negatively and significantly affect the form of representation that the bank wishes to establish. Barriers can be government-created; for example, some governments can impose stringent measures in issuing business licenses to foreign firms and stringent capital requirements. Earlier, Miller and Parkhe (1998) proved that countries with less stringent and lower taxes were preferred by multinational banks.

\section{CONCLUSION}

The main objective of this study was to investigate the barriers and challenges constraining Zimbabwean banking institutions in going multinational. An analysis of the Zimbabwean banking sector was done and revealed that it faces a number of problems, such as lack of liquidity, lack of corporate governance, and several other problems. Various studies have shown that MNEs from developing countries face huge difficulties when they go multinational. Literature conducted on the challenges that MNBs face when they go international listed a number of factors that affect banks. Financial regulation, language barriers, cultural differences, and economic reasons were cited as the challenges that banks face when going multinational. To achieve its objective, the study used questionnaires and interviews to obtain information on why Zimbabwean banks do not go multinational. Findings from the study showed that adjusting to the foreign environment, managing change within the organisation, and managing political risk are the barriers that banks faced in going multinational. The study further revealed that banks face challenges such as cultural differences, information asymmetry, government policies, legal and regulatory barriers, level of technology, and government policies.

\section{POLICY RECOMMENDATIONS}

Based on the findings, the study recommends the following measures. There is need, by the Reserve Bank of Zimbabwe, to develop and implement sound financial policies that allow for an efficient domestic banking system. Such financial policies create a platform that facilitates the development of stable institutions that can compete on regional and international markets. The establishment of a strong banking sector that competes on international platforms requires both government support and conducive financial sector policies. The government should also assist banks when they want to go multinational. There are several ways in which the Zimbabwean 
governments can do so. First is information gathering and dissemination. The government should gather and disseminate information to local banks about attractive destinations, both regionally and internationally. Second, the government can liaise with regional countries on regional platforms for the promotion of regional financial market integration. Regional integration has the potential to help banking institutions reduce the challenges and barriers that banks face when going multinational.

\section{AUTHOR INFORMATION}

Courage Mlambo is a $\mathrm{PhD}$ (Economics) candidate at the University of Fort Hare's School of Business Management and Economics, South Africa. E-mail: mlamboct@gmail.com (Corresponding author).

David Mapondera is a student (Banking and Finance) at the National University of Science and Technology‘s School of Banking and Finance, Zimbabwe. Email: maponderadavid89@gmail.com.

Morris Tenderere is a Masters student (Economics) at the University of Fort Hare's School of Business Management and Economics. Email: raymondtenderere@gmail.com.

\section{REFERENCES}

Aguiar, S., Aguiar-Conraria, L., Gulamhussen, M. A., \& Magalhães, P. C. (2011). "Foreign direct investment and home-country political risk: the case of Brazil", Latin American Research Review 47 (2), 144-165.

Azzimonti, M., \& Sarte, P. G. (2007). "Barriers to Foreign Direct Investment Under Political Instability", Economic Quarterly, 93 (3), 287-315.

Ball, C. A., \& Tschoegl, A. T. (1982). "The decision to establish a foreign bank branch or subsidiary: An application of binary classification procedures". Journal of Financial and Quantitative Analysis, 17:411-424.

Banerjee, C., \& Tiwari, R. (2009). "Emergence of Indian Multinationals in Germany: An Analysis of Critical Success Factors Results of a TUHH Study". Retrieved from: http://www.globalinnovation.net/publications/PDF/Indian-FDI-CSF-pre.pdf (November 23, 2014).

Blandón, J. G. (1998). "The choice of the form of representation in multinational banking: Evidence from Spain". Retrieved from: http://www.econ.upf.edu/docs/papers/downloads/271.pdf (November 16, 2013).

Buch, C. M., \& DeLong, G. (2004). “Cross-Border Bank Mergers: What Lures the Rare Animal?” Journal of Banking and Finance, 28:2077-2102.

Büthe, T., \& Milner, H. V. (2008). "The politics of foreign direct investment into developing countries: increasing FDI through international trade agreements?”, American Journal of Political Science, 52:741-762.

Cerutti, E. (2007). "How banks go abroad: Branches or subsidiaries?" November 15. http://siteresources.worldbank.org/DEC/Resources/How_banks_go_abroad_Branches_or_subsidiaries.pdf.

Chikoko, L. (2014). "Potential Sources of Zimbabwe Commercial Banks Illiquidity after Dollarization". Journal of Contemporary Issues in Business Research, 3:41-51.

Claessens, S., \& Van Horen, N. (2012). "Foreign Banks: Trends, Impact and Financial Stability”. November 17. http://www.imf.org/external/pubs/ft/wp/2012/wp1210.pdf.

Claessens, S., \& Van Horen, N. (2008). "Location Decisions of Foreign Banks and Institutional Competitive Advantage." Netherlands: De Nederlandsche Bank.

Coval, J., \& Moskovitz, T. (1999). "Home Bias at Home: Local equity Preference in Domestic Portfolios". Journal of Finance, 54:2045-2073.

Cull, R., \& Peria, M. S. (2010). "Foreign Bank Participation In Developing Countries: What Do We Know About The Drivers And Consequences Of This Phenomenon?" November 16. http://elibrary.worldbank.org/doi/book/10.1596/1813-9450-5398.

Creswell, J. W. (2003). Research Design: Qualitative, Quantitative and Mixed Method Approaches. Carlifonia: Thousand Oak: Sage Publication.

Dixit, A. (2012). “Governance, Development, and Foreign Direct Investment”. February 15. http://www.princeton.edu/ dixitak/home/WeberLectFinal.

Focarelli, D., \& Pozzolo, A. (2000). “The Determinants of Cross-Border Shareholding: An Analysis with BankLevel Data from OECD Countries." Italy:Bank of Italy.

Galindo, A., Micco, A., \& Serra, C. (2002). “Better the Devil that You Know: Evidence on Entry Costs Faced by 
Foreign Banks", Inter-American Development Bank.

Globerman, S., \& Shapiro, D. (2002). "Global Foreign Direct Investment Flows: The Role of Governance Infrastructure", Elsevier, 30:1899-1919.

Grubel, H. G. (1985). "Multinational Banking”. Singapore:Institute of South East Asian Studies.

Guler, I., \& Guillén, M. F. (2009). "Home Country Networks And Foreign Expansion: Evidence From The Venture Capital Industry". November 20. http://www-management.wharton.upenn.edu/guillen/PDF Documents/VC_Networks_AMJ-2010.pdf.

Hamadou. B. (2012). "An Empirical Study On Multinational Banks Decision To Go Abroad”. November 20. http://connection.ebscohost.com/c/articles/77781944/empirical-study-multinational-banks decision-goabroad.

Herrero, A. G., \& Simón, D. N. (2003). "Determinants And Impact Of Financial Sector FDI To Emerging Economies: A Home Country's Perspective (1). November 20. http://papers.ssrn.com/sol3/papers.cfm?abstract_id=510942.

Hryckiewicz, A., \& Kowalewski, O. (2008). "Economic determinants and entry modes of foreign banks into Central Europe". November 20. http://fic.wharton.upenn.edu/fic/papers/08/0808.pdf.

Hultman, C. W., \& McGee, R. L. (1989). "Factors affecting the foreign banking presence in the US", Journal of Banking and Finance, 13: 383-396.

Iloiu, M., \& Iloiu, S. (2008). "Risk and Investment Decision. Fascicle of Management and Technological Engineering, Volume VII (XVII).

Jensen, N. M. (2006). "Nation-states and the multinational corporation". Princeton, NJ: Princeton University Press.

Wu, Ji., Jeon, Bang Nam, \& Luca, Alina C. (2010). "Does distance affect the performance of foreign banks? Evidence from multinational banking in developing countries", International Finance Review, 11:580-603.

Wu, Jianlian. (2008). An Analysis of Business Challenges Faced by Foreign Multinationals Operating the Chinese Market. International journal of business management. 3: 169-173.

Kessapidou, S., \& Varsakelis, N. C. (2002). "The impact of national culture on international business performance: the case of foreign firms in Greece", European Business Review, 14:268-275.

Lee, B. (2002). "The Determinants of Foreign Banks' Entry in Korea and Its Effects on Korean Domestic Banks' Performance," Economic Papers, 6:42-65.

Lensink, R., \& Hermes, N. (2003). "The short-term effects of foreign bank entry on domestic bank behaviour: does economic development matter". March 15: http://www.rug.nl/staff/c.l.m.hermes/foreign_banks_and_economic_development.pdf.

Marin, D. (2010). “Are Multinational Banks Different?” March 15. www.iwb.vwl.unimuenchen.de/.../ver.../econ_pol_multi_banks.doc.

Mathews, J. A. (2002). Dragon multinational: Towards a new model of global growth New York: Oxford University Press.

Miller, S., \& Parkhe, A. (1998). "Patterns in the expansion of U.S. bank's foreign operations", Journal of international business studies, 29:359-390.

Mphambela, C. (2012). "Bank failures: The underlying factors". March 15. http://www.theindependent.co.zw/2012/06/22/bank-failures-the-underlying-factors/.

Mutinelli, M., \& Piscitello, L. (2001). "Foreign direct investment in the banking sector: the case of Italian banks in the '90s", International Business Review, 10:661-685.

Muza, O. (2007). "A Study of the Critical Success Factors and Drawbacks for Cross-border Investments - A Case for the Banking Sector in Zimbabwe. March 15. http://www.scribd.com/doc/33365760/A-Study-of-theCritical-Success-Factors-and-Drawbacks-for-Cross-Border-Investments-A-Case-for-the-Banking Sector-inZimbabwe.

Naaborg I. (2007). "Foreign Bank Entry and Performance: with a focus on Central and Eastern Europe". November 26. http://dissertations.ub.rug.nl/faculties/eco/2007/i.j.naaborg/.

Nigh D., Cho, K. R., \& Krishnan, S. (1986). "The role of location - related factors in U.S. banking involvement abroad: An empirical examination”, Journal of International Business Studies, 17:59-72.

Njanike, K. (2009). "The impact of effective credit risk management on bank survival". April 27. http://rmr.lixin.edu.cn/files/100134/1110/109_1392b787e1b.pdf.

Petrou, A. (2007). Multinational banks from developing versus developed countries: Competing in the same area? April 27. http://www.sciencedirect.com/science/article/pii/S1075425307000506?np=y.

Reserve Bank of Zimbabwe. (2013). Monetary Policy Statement by Gideon Gono. March 03. 
http://www.rbz.co.zw/pdfs/2013\%20MPS/Jan\%202013\%20MPS.pdf.

Tsarwe, L. (2014). "Stamp out mismanagement". June 06. http://www.herald.co.zw/stamp-out-mismanagement/.

Ursacki, T., \& Vertinsky, I. (1992). Choice of entry timing and scale by foreign banks in Japan and Korea". Journal of Banking and Finance, 16:405-421.

Wu, J. (2008). "An Analysis of Business Challenges Faced by Foreign Multinationals Operating the Chinese Market". International Journal of Business Management 3:169-174.

Wu, J., Jeon, B. N., \& Luca, A. (2010). "Does distance affect the performance of foreign banks? Evidence from multinational banking in developing countries". March 15. http://mpra.ub.unimuenchen.de/37083/1/Does_distance_affect_the_performance_by_Wu_Jeon_Luca_MPR A2.pdf.

Zhang J., Shan, J., \& Wang, S. (2013). "Location strategies of multinational banking under risk and asymmetric information", Nankai Business Review International, 4:130-146. 